\title{
Finite Element Modeling and Numerical Simulation of Welding at the Repair of Gas Pipelines with Steel Sleeve
}

Radoslav Konar ${ }^{1}$, Milos Mician ${ }^{1}$, Marek Patek ${ }^{1}$, Dalibor Kadas ${ }^{2}$

${ }^{1}$ Department of Technological Engineering, Faculty of Mechanical Engineering, University of Zilina, Univerzitna 8215/1, 01026 Zilina. Slovak Republic. E-mail: radoslav.konar@fstroj.uniza.sk, milos.mician@fstroj.uniza.sk, marek.patek@fstroj.uniza.sk

${ }^{2}$ INA Kysuce, spol. s r. o., Dr. G. Schaefflera 1, 02401 Kysucke Nove Mesto, Slovak Republic. E-mail: kadasdli@schaeffler.com

This article deals with simulations of the welding process for applications of practice using SYSWELD software. Simulation of welding at the repair of high-pressure gas pipeline with steel sleeve with composite filling is presented in this paper. Two welds connecting the distance ring and gas pipe were simulated. Structure of programme SYSWELD and repair of high pressure gas pipeline with steel sleeve is described in theoretical part of article. Preparation of boundary conditions for numerical simulation on real sample and numerical simulation of welding is in experimental part. Thermal fields, residual stresses and hardness were simulated. The results of the numerical model, which are listed in article except for residual stresses are compared to real experiments. This article mainly describes the numerical simulation capabilities in welding simulation programme SYSWELD.

Keywords: Sysweld, Steel L360NB, Numerical simulations, Repair of gas pipeline

\section{Acknowledgement}

This work has been supported by the Scientific Grant Agency of the Ministry of Education of the Slovak Republic, grant VEGA: 1/0836/13, KEGA: 034ZU-4/2015.

\section{References}

[1] JOSEPH, A. et al. (2005) Evaluation of residual stresses in dissimilar weld joints. In: International Journal of Pressure Vessels and Piping, Vol. 82, pp. $700-705$.

[2] TOTTEN, G., HOWES, M., INOUE, T. (2002). Handbook of Residual Stress and Deformation of Steel. AMS International, USA, ISBN 0-87170-729-2

[3] MORAVEC, J. (2011). Influence of Welding Parameters on Weld Pool's Geometry in Shielding Gas Welding. Pollypress, Liberec

[4] DENG, D., MURAKAWA, H. (2006). Numerical simulation of temperature field and residual stress in multi-pass welds in stainless steel pipe and comparison with experimental measurements. In: Computational Materials Science, Vol. 37, pp. 269 - 277.

[5] WANG, Y. et al. (2013). Simulation and analysis of temperature field for in-service multi-pass welding of a sleeve fillet weld. In: Computational Materials Science, Vol. 68, pp. 198 - 205.

[6] ZMINDAK, M., MESKO, J., PELAGIC, Z., ZRAK, A. (2014). Finite Element Analysis of Crack Growth in Pipelines. In: Manufacturing Technology, Vol. 14, No. 1, pp. 116 - 122.

[7] MESKO, J., ZRAK, A., MULCZYK, K., TOFIL, S. (2014). Microstructure analysis of welded joints after laser welding. In: Manufacturing technology, Vol. 14, No. 3, pp. 355-359. J.E. Purkyne University, Ústi nad Labem.

[8] MORAVEC, J., NOVAKOVA, I., BRADAC, J. (2016). Effect of Age Hardening Conditions on Mechanical Properities of AW 6082 Alloy Welds. In: Manufacturing technology, Vol. 16, No. 1, pp. 192-198. J.E. Purkyne University, Usti nad Labem.

[9] NOVAK, P., MESKO, J., ZMINDAK, M. (2013). Finite element implementation of Multi-pass Fillet Weld with Phase Changes. In: Manufacturing Technology, Vol. 13, No. 1, pp. 79 - 85.

[10]MICIAN, M., PATEK, M., SLADEK, G. (2014). Concept of Reapiring Branch Pipes on High-pressure Pipelines by Using split Sleeve. In: Manufacturing technology, Vol. 14, No. 3, pp. 60-66. J.E. Purkyne University, Ústi nad Labem.

[11]BRUNA, M., KUCHARCIK, L., SLADEK, A. (2013). Complex evaluation of porosity in A356 alluminium alloy using advanced porosity module. In: Manufacturing technology, Vol. 13, No. 1, pp. 26-30. J.E. Purkyne University, Usti nad Labem. 